\title{
STRUCTURE AND DISTRIBUTION OF GLANDULAR AND NON-GLANDULAR TRICHOMES ON ABOVE-GROUND ORGANS IN Inula helenium L. (Asteraceae)
}

\author{
Aneta Sulborska \\ Department of Botany, University of Life Sciences in Lublin, Akademicka 15, 20-950 Lublin, Poland \\ aneta.sulborska@up.lublin.pl
}

Received: 17.06.2013

\begin{abstract}
Micromorphology and distribution of glandular and non-glandular trichomes on the above-ground organs of Inula helenium L. were investigated using light and scanning electron microscopy (SEM).

Two types of biseriate glandular trichomes, i.e. sessile and stalk hairs, and non-glandular trichomes were recorded. Sessile glandular trichomes were found on all examined I. helenium organs (with their highest density on the abaxial surface of leaves and disk florets, and on stems), whereas stalk glandular trichomes were found on leaves and stems. Sessile trichomes were characterised by a slightly lower height $(58-103 \mu \mathrm{m})$ and width (32-35 $\mu \mathrm{m})$ than the stalk trichomes $(62-111 \mu \mathrm{m} \times 31-36 \mu \mathrm{m})$. Glandular hairs were composed of 5-7 (sessile trichomes) or 6-9 (stalk trichomes) cell tiers. Apical trichome cell tiers exhibited features of secretory cells. Secretion was accumulated in subcuticular space, which expanded and ruptured at the top, and released its content. Histochemical assays showed the presence of lipids and polyphenols, whereas no starch was detected.

Non-glandular trichomes were seen on involucral bracts, leaves and stems (more frequently on involucral bracts). Their structure comprised 2-9 cells; basal cells (1-6) were smaller and linearly arranged, while apical cells had a prozenchymatous shape. The apical cell was the longest and sharply pointed. Applied histochemical tests revealed orange-red (presence of lipids) and brow colour (presence of polyphenols) in the apical cells of the trichomes. This may suggest that beside their protective role, the trichomes may participate in secretion of secondary metabolites.
\end{abstract}

Key words: external secretory tissue, trichomes, Inula helenium, Asteraceae

\section{INTRODUCTION}

Inula helenium is a large (up to $2 \mathrm{~m}$ high) perennial growing in North America, Europe, Asia Minor, and Japan. In Poland, it usually occurs in scrubs, felling sites, and near rivers; it is also cultivated in herb plantations [1] due to its cholagogic, diuretic, anthelmintic, and expectorant properties [2].

Likewise in many other representatives of Asteraceae [3-5], the above-ground organs of the species bear glandular and non-glandular trichomes. Substances produced by glandular trichomes may function as repellents against herbivores and pathogens $[6,7,8]$, limit the transpiration rate, and reduce leaf temperature [9]. Withering and falling leaves with intact glandular hairs may also provide a phytotoxic environment for germinating seeds and growing seedlings [6]. In contrast, non-glandular trichomes often act as a physiological barrier against herbivores and contribute to plant adaptation to environmental conditions, particularly in dry environments $[10,11]$.

Glandular trichomes in representatives of the Asteraceae family are biseriate and form 3-4 vertical tiers [12], 5 tiers [6,7,13-19], 5-6 tiers [11,20] or 6-7 tiers [8]. In Asteraceae representatives, have been described trichomes consisted of a large mulicellular stalk (16-40 cells) and a mulicellular secreting head (60-120 cells arranged in two zones) [19]. Milan et al. [21] have described uniseriate glandular trichomes with a multicellular stalk and a globular or spatulate apical cell. Other researchers have found Asteraceae trichomes to be biseriate, multicellular, sessile or stalked, with a head composed of 1 or 2 pairs of achlorophyllous apical cells and 2-3 pairs of chlorophyllcontaining cells [3-5]. Ramayya [22] has reported four structural models of glandular trichomes in Asteraceae representatives: filiform, macroform, biseriate, and multiseriate hairs. According to B ondarev et al. [12], the individual trichome tiers are formed of ontogenetically different cells. 
Covering trichomes in Asteraceae are composed of different numbers of cells with a varied degree of viability. Metcalfe and Chalk [23] have described eight types of mechanical hairs, including uniseriate trichomes with an elongated apical cell, Tshaped hairs, or peltate trichomes. Cornara et al. [18] have distinguished two types of covering hairs in Stevia rebaudiana: long $(210-650 \mu \mathrm{m})$ and rough hairs and short $(85-170 \mu \mathrm{m})$ and smooth trichomes.

In Asteraceae representatives, both types of trichomes (glandular and non-glandular) are located primarily on leaves $[7,9,11,24]$ with the highest density observed on the abaxial surface of the epidermis. The other organs that bear trichomes are stems $[9,15]$, involucral bracts $[11,18,19]$, and corollas $[13,14,17,18$, $25,26]$.

Glandular trichomes in Asteraceae accumulate a variety of substances, e.g. essential oils [11,19,27], tannins, flavonoids [19], terpenoids $[6,13,16,18,19]$, lipids [9], polysaccharides [8,9], proteins [9,18], phenols [18], alkaloids [16,18] and oleoresin [16].

There are no detailed data in the available literature about Inula helenium trichomes. Spring [26] merely mentions the presence of glandular trichomes on the bottom of the anthodium in this species, but provides no description of their structure. The aim of the study was to determine the types of trichomes in Inula helenium and to assess the quality of glandular secretion of the trichomes.

\section{MATERIALS AND METHODS}

The Inula helenium L. plants examined were obtained from the collection of the UMCS Botanical Garden, Lublin.

Trichomes were observed on stems, leaves, and flowers under light and scanning electron microscopes. Location of glandular and mechanical trichomes was identified and morphometric (length and width measured at the widest point) and structural (micromorphology, cell number and arrangement, some aspects of anatomy) analyses were performed.

LM. Cross-sections of stems, leaves, and involucral bracts were made manually from fresh and $70 \%$ ethanol fixed material; additionally, fragments of ray-floret and disk-floret corollas were used. Some plant sections were stained with toluidine blue and safranin, and others were tested for the presence of lipids (Sudan III and Sudan Red B), polyphenols $\left(\mathrm{FeCl}_{3}\right)$, and starch (IKI).

Additionally, semi-thin (approximately $15-\mu \mathrm{m}$ thick) permanent paraffin preparations were made. Stem and leaf fragments were fixed in $70 \%$ ethanol, dehydrated in graded alcohol and Poly/Clear Solvent series and embedded in Poly-Fin paraffin $\left(40^{\circ} \mathrm{C}\right)$. The samples were cut with the use of an MPS-ZU 4.2 microtome. Paraffin was removed by repeated washing with an increasing gradient of the Poly/Clear Solvent. The sections were stained with $0.05 \%$ toluidine blue or $0.1 \%$ safranin with $1 \%$ fast green, and sealed in Euparal. The observations were carried out and photographs were taken under a Nikon Eclipse 400 light microscope.

SEM. Stem and leaf fragments were fixed in a 4\% glutaraldehyde solution in $0.1 \mathrm{M}$ phosphate buffer (pH 7.0, temp. $4^{\circ} \mathrm{C}$ ) for 12 hours. Next, the material was washed with the same buffer 4 times for 20 minutes and dehydrated in graded ethanol series up to absolute. In successive steps, the plant samples were transferred to acetone, critical point dried in liquid $\mathrm{CO}_{2}$ using Bal-Tec CPD 030, and sputter-coated with Polaron SC 7640. The surface of the epidermis of the analysed organs was observed and photographed under a scanning electron microscope BS 301 coupled with a Tescan attachment for digital processing of microscopic images.

\section{RESULTS}

On the above-ground organs of Inula helenium (Fig. 1 A, B) were found glandular and non-glandular trichomes.

\section{Glandular trichomes}

Glandular trichomes had a characteristic layered (biseriate) structure. Two types of these hairs were observed: stalked and sessile. Sessile trichomes were more abundant and they were found on the leaves (Figs $2 \mathrm{~A}$; $3 \mathrm{~B}, \mathrm{D} ; 4 \mathrm{~A}, \mathrm{D}, \mathrm{E})$, primarily on the abaxial epidermis, stems (Figs $2 \mathrm{H} ; 3 \mathrm{~A}, \mathrm{C}, \mathrm{E}-\mathrm{G}$ ), involucral bracts (adaxial and abaxial epidermis) (Fig. 4 C), ray-floret corolla (abaxial surface) (Fig. $3 \mathrm{H}$ ) and in the apical teeth of the disk-floret corolla (abaxial surface). Stalk trichomes were less abundant and they were only found on the leaves (Fig. 3 K, L) and stems (Figs 2 B; 3 I, J).

The stalk trichomes were composed of stalk and secretory cells arranged in two vertical rows. The stalk cells were arranged less regularly, while the secretory cells formed distinct tiers (Fig. 3 I-L). The number of stalk trichome tiers varied between 6 and 9 (Table 1). The height of the trichomes ranged of 62-111 $\mu \mathrm{m}$. Trichomes located on stems were slightly longer than those on leaves. The average width of the hairs was $31 \mu \mathrm{m}$ (leaves) and $36 \mu \mathrm{m}$ (stems). The stalk cells were characterised by larger sizes (compared with secretory cells) and they were radially elongated (Fig. $3 \mathrm{I}-\mathrm{L}$ ). Cells of stalk in mature hairs exhibited a high degree of vacuolisation. In the longitudinal section, the secretory cells were rectangular and slightly flattened (Fig. 3 I-L), and only the apical cell pair was characterised by larger sizes and an oval shape. Dense cytoplasm content was observed in all secretory cells of young trichomes. At the pre-sectory stage, five of the apical cell pairs exhibited a dense 
protoplast and the other cells were dominated by a large central vacuole (Fig. 3 J-L).

The sessile trichomes were formed by $5-7$ cell tiers. The mean height of the trichomes ranged between $58 \mu \mathrm{m}$ and $103 \mu \mathrm{m}$ and the width from 32 to $35 \mu \mathrm{m}$ (Table 1). Apical cells of the hair were characterised by larger sizes than the other trichome cells (Fig. 3 A-G). At the pre-secretory stage (Fig. $3 \mathrm{~F}, \mathrm{G}$ ), the trichomes exhibited dense cytoplasm in all cell tiers. At a later developmental stage, only the apical cell pair of the trichome was characterised by a dense protoplast, while the other cells were strongly vacuolated (Fig. 3 A, B, E).

In the successive developmental stages of both types of trichomes, the cuticle surrounding the apical cells detached, thus forming a spherical or oval container for secretions released by the cellulose walls of the apical cells (Figs 3 A, B, H; 4 A-C, E). The subcuticular space expanded as the secretion amounts increased, and ruptured thereby releasing its content (Figs 3 C, D, I; 4 D). Simultaneously, the enlargement of the subcuticular space was accompanied by degeneration of trichome cells and collapse thereof beginning with the top tiers of the trichomes (Fig. $3 \mathrm{H}, \mathrm{I}$ ).

Histochemical tests have revealed that trichomes produce and secrete lipids (Figs $3 \mathrm{C}$, J; 4 A-C) and polyphenols (Fig. 4 D, E). Both substances were found mainly in the apical cell layer, both in their protoplast and the subcuticular space. Starch was not found in the analysed trichome cells.

\section{Non-glandular trichomes}

Besides glandular trichomes, covering hairs were also found in the investigated species; these were located mainly on the involucral bracts and less frequently on leaves (Figs $1 \mathrm{C}-\mathrm{F} ; 2 \mathrm{~A}$; 4 F) and stems (Fig. 2 B-I). These trichomes were usually present on the abaxial surface of these organs. Their length was

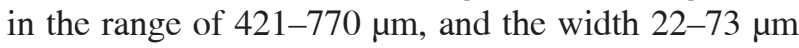
(Table 2). The trichomes were 2-9 celled. Their basal part (Figs 1 E; 2 C-I; 4 F) was composed of linearly arranged 1-6 cells (most frequently 3 ) with similar shapes and sizes in the longitudinal section. The upper parts of the trichomes comprised 1-3 prozenchymatous cells (Table 2) that were considerably longer than cells located in the lower part. The apical cell was the longest, narrowest, and sharply tapered (Figs 1 D; 2 D-F). The trichomes in Inula helenium were both erect and inclined towards the organ surface (Figs $1 \mathrm{C}-\mathrm{F} ; 2 \mathrm{~A}-\mathrm{I}$ ). The cells of covering trichomes were characterised by a thick cell wall (Fig. 2 D, G-I) and a viable protoplast. Their cytoplasm frequently contained chloroplasts.

Histochemical assays applied to glandular hairs revealed a positive reaction of non-glandular trichomes to Sudan Red B (Figs $2 \mathrm{C}$; 4 A) and $\mathrm{FeCl}_{3}$ (Fig. 4 F), which indicates presence of lipids and polyphenols. Typically, elongated apical trichome cells were stained (Fig. 2 C). Besides their covering role, the trichomes may have served a secretory function.

Table 1

Distribution and morphological characteristics of glandular trichomes located on above-ground organs of Inula helenium

\begin{tabular}{ccccccccc}
\hline \multirow{2}{*}{ Plant organ } & \multirow{2}{*}{$\begin{array}{c}\text { Type of } \\
\text { trichomes }\end{array}$} & \multirow{2}{*}{$\begin{array}{c}\text { Number of trichome } \\
\text { cell tiers }\end{array}$} & \multicolumn{3}{c}{ Height $(\mu \mathrm{m})$} & & \multicolumn{3}{c}{ Diameter* $(\mu \mathrm{m})$} \\
\cline { 4 - 9 } & & & Min. & Max. & Mean & Min. & Max. & Mean \\
\hline \multirow{2}{*}{ Stem } & Sesille & $5-7$ & 41.1 & 82.2 & $\mathbf{6 2 . 5}$ & 28.3 & 38.6 & $\mathbf{3 2 . 9}$ \\
& Stalk & $7-9$ & 69.4 & 110.5 & $\mathbf{8 8 . 7}$ & 30.8 & 41.1 & $\mathbf{3 6 . 3}$ \\
\hline \multirow{2}{*}{ Leafe } & Sesille & $5-6$ & 51.4 & 64.3 & $\mathbf{5 8 . 0}$ & 25.7 & 38.6 & $\mathbf{3 2 . 7}$ \\
& Stalk & $6-8$ & 61.7 & 102.8 & $\mathbf{8 7 . 4}$ & 25.7 & 38.6 & $\mathbf{3 0 . 8}$ \\
\hline \multirow{2}{*}{ Rey-floret } & Sesille & 6 & 64.3 & 87.4 & $\mathbf{7 7 . 1}$ & 25.7 & 36.0 & $\mathbf{3 2 . 2}$ \\
Disk-floret & Sesille & 6 & 64.3 & 90.0 & $\mathbf{7 7 . 1}$ & 25.7 & 38.6 & $\mathbf{3 1 . 9}$ \\
Involuclar bract & Sesille & $5-6$ & 92.5 & 118.2 & $\mathbf{1 0 3 . 2}$ & 28.3 & 48.8 & $\mathbf{3 5 . 0}$ \\
\hline
\end{tabular}

*The diameter was measured at the widest place of trichome

Table 2

Some features characterising non-glandular trichomes found on above-ground organs of Inula helenium

\begin{tabular}{|c|c|c|c|c|c|c|c|c|c|}
\hline \multirow{2}{*}{ Plant organ } & \multicolumn{3}{|c|}{ Number of trichome cells } & \multicolumn{3}{|c|}{ Height $(\mu \mathrm{m})$} & \multicolumn{3}{|c|}{ Width* $^{*}(\boldsymbol{\mu m})$} \\
\hline & Min. & Max. & Mean & Min. & Max. & Mean & Min. & Max. & Mean \\
\hline Stem & 2 & 4 & 5.7 & 334.1 & 565.4 & 512.9 & 36.0 & 69.4 & 55.7 \\
\hline Leaf & 3 & 9 & 5.9 & 385.5 & 462.6 & 420.8 & 61.7 & 82.2 & 72.9 \\
\hline Involuclar bract & 2 & 4 & 2.9 & 77.1 & 295.7 & 187.1 & 23.1 & 56.5 & 34.4 \\
\hline
\end{tabular}

*Width measured at the widest point of trichome 

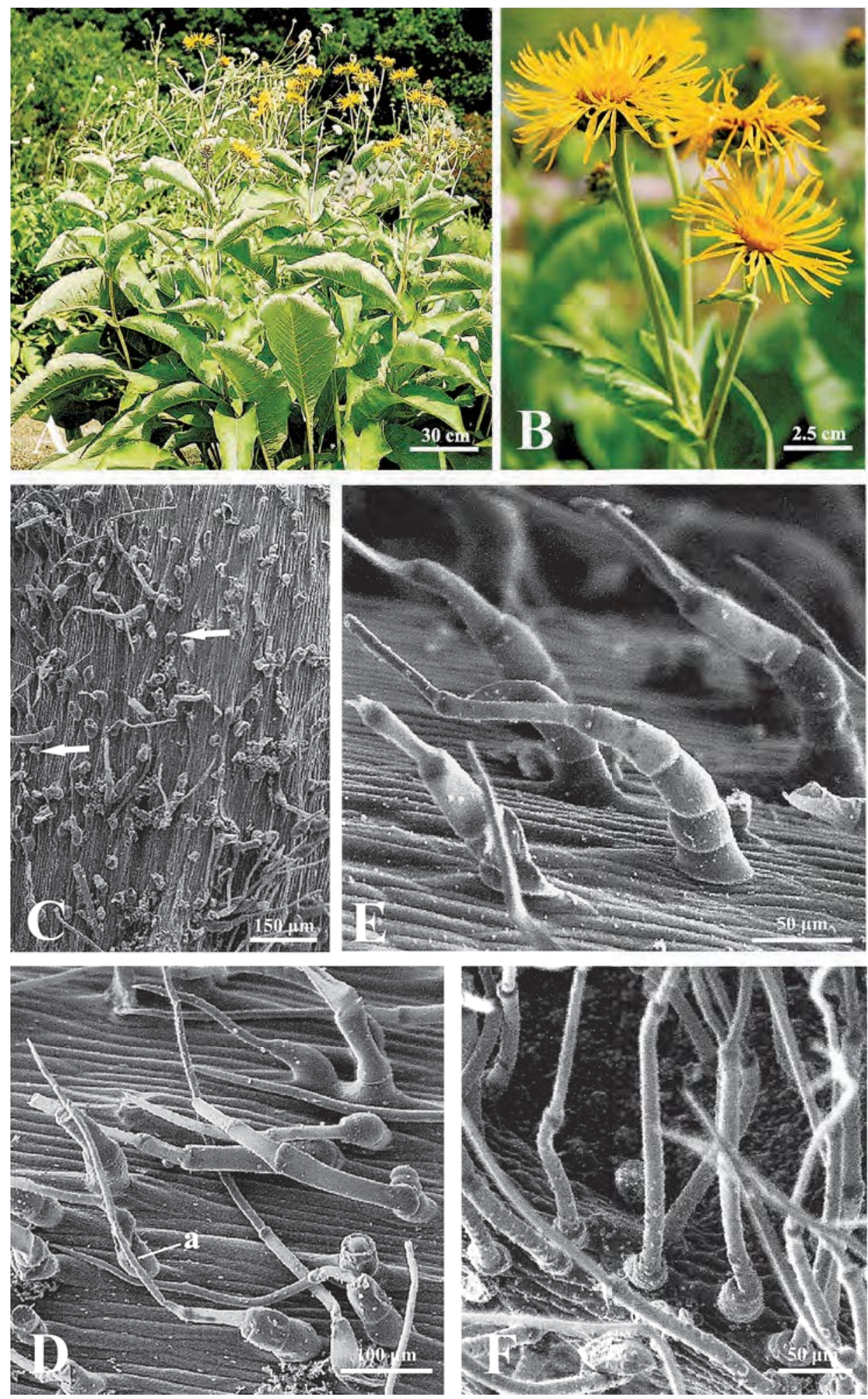

Fig. 1. Flowering plants and surface of epidermis of I. helenium leaves.

A. General view of plants.

B. Anthodia in full blooming.

C, D. Parts of the abaxial surface of the leaf (main vein) with visible glandular and non-glandular trichomes (arrows); a apical cell of trichome.

E, F. Non-glandular trichomes on the abaxial surface of the leaf (E - main vein of the leaf, F - leaf blade). 

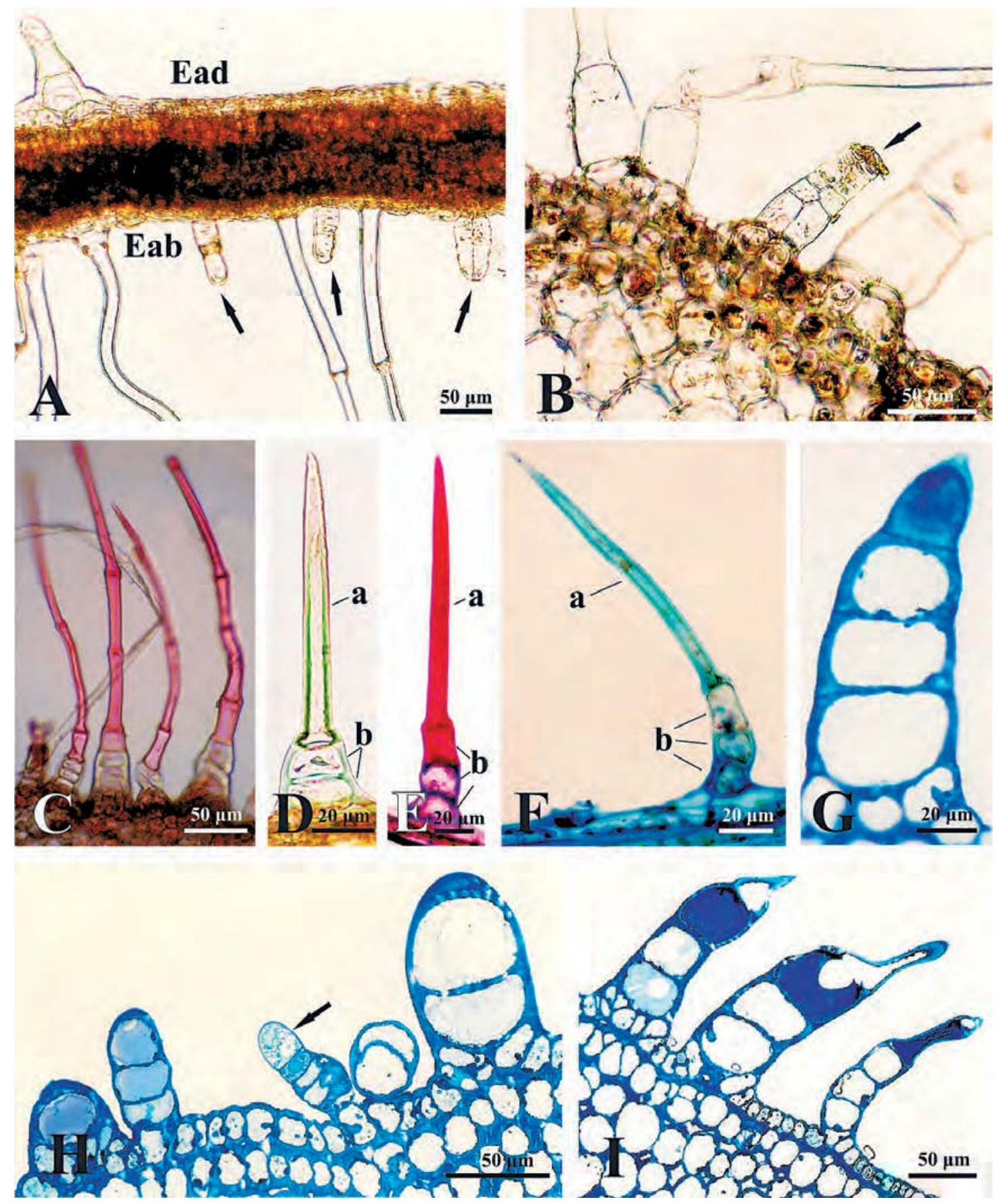

Fig. 2. Different types of trichomes on I. helenium stem and leaves.

A. Fragment of leaf cross-section with visible non-glandular and glandular (arrows) trichomes (Ead - adaxial epidermis, Eab - abaxial epidermis).

B. Fragment of stem cross-section. Arrow shows a stalk glandular trichome.

C-F. Mature non-glandular trichomes on the surface of the stem (b-basal cells, a - apical cell).

G-I. Non-glandular trichomes in different developmental stages on the stem surface. Arrow in photo H shows a sessile glandular trichome seen in lateral view.

A-D - hand made sections without staining (A, B, D) and treated with Sudan Red B (C); E-I - semi-thin sections stained with safranin (E) and toluidine blue (F-I). 

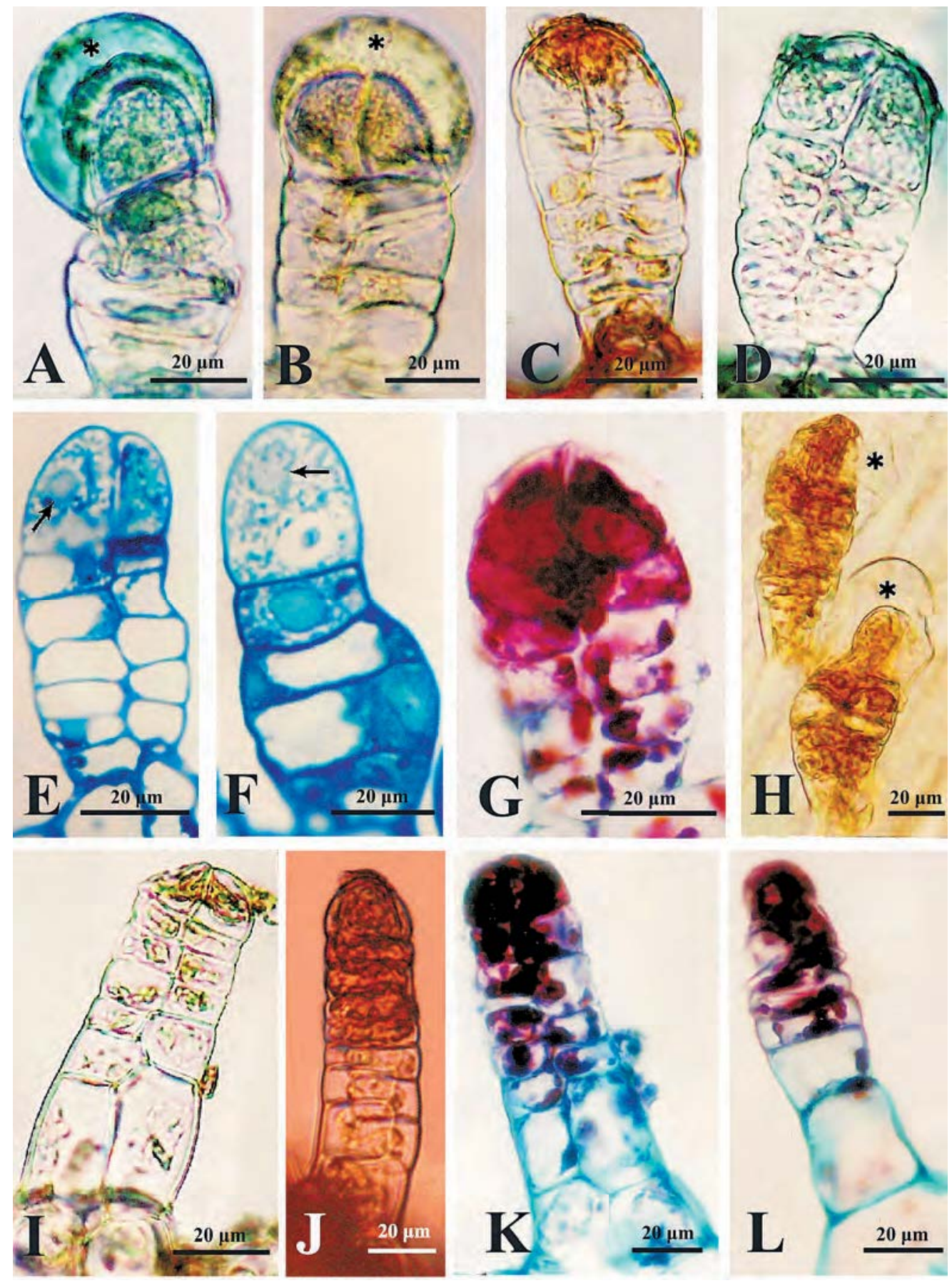

Fig. 3. Glandular trichomes on the surface of I. helenium stem, leaves and flowers.

A-D. Sessile glandular trichomes on the surface of stem (A, C) and leaf (B, D) in different developmental stages. Stars show subcuticular space filled with secretion (hand-made sections stained with toluidine blue (A, D), Sudan III (C) and without staining (B)).

E-G. Sessile glandular trichomes on the stem surface. Dense cytoplasm and cell nucleus (arrows) visible in the apical tier of cells. Strong vacuolisation of basal cells of trichome visible in picture E (semi-thin sections stained with toluidine blue $(\mathrm{E}, \mathrm{F})$ and safranin $(\mathrm{G})$; trichome in picture $\mathrm{F}$ seen in lateral view).

H. Trichomes on the abaxial surface of the corolla of ray floret. Stars show subcuticular space filled with secretion (handmade section without staining).

I-J. Stalk glandular trichomes on the abaxial surface of stems (I - view of the front; J - lateral view; handmade sections without staining (I) and stained with Sudan Red B (J).

K-L. Stalk glandular trichomes on the surface of leaves (semi-thin sections stained with safranin and fast green; K - view of the front, $\mathrm{L}$ - lateral view). 

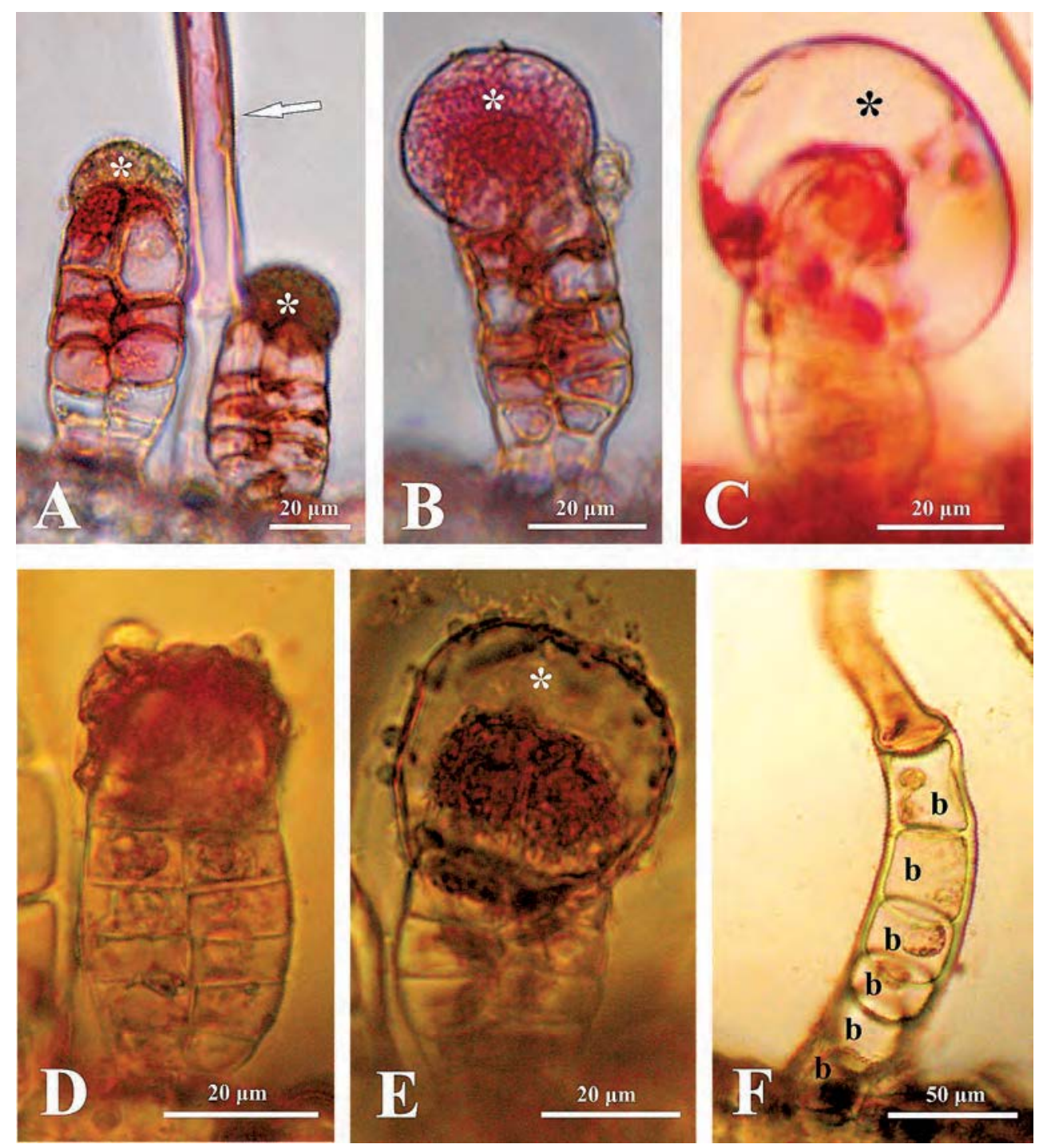

Fig. 4. Glandular and non-glandular trichomes of I. helenium after applying histochemical tests.

A-C. Sessile glandular trichomes and non-glandular trichomes (arrow) on the leaves (A, B) and on the involuclar bract surface (C) treated with Sudan Red B (stars show subcuticular space).

D, E. Sessile glandular trichomes on the leaf stained with $\mathrm{FeCl}_{3}$ (star shows subcuticular space).

F. Non-glandular trichome on the leaf treated with $\mathrm{FeCl}_{3}$ (b-basal cells).

\section{DISCUSSION}

Above-ground parts of 20-30\% vascular plants are covered by glandular trichomes, which are represented by over 300 different morphological forms [28]. The above-ground organs of Inula helenium exhibited biseriate glandular trichomes. Similar hairs were most frequently described in other representatives of the family Asteraceae $[15,16,18,20,29,30]$. In the species investigated in the present paper, two types of glandular trichomes were reported, i.e. sessile and stalk hairs, which corresponds with the reports of Inula viscosa trichomes provided by $\mathrm{W}$ erker and $\mathrm{Fahn}$ [9]. The number of tiers forming Inula viscosa trichomes varied from 5 to 8 , depending on the location of the hairs on the plant, which partially corresponds with the results concerning glandular trichomes in Asteraceae presented by other researchers [6-8,11,13-20].

The findings of the present investigations have shown that the height and width of glandular trichomes were 63-103 $\mu \mathrm{m}$ and 21-36 $\mu \mathrm{m}$, respectively, depending on their location on the plant. These data correspond partially with the parameters reported for other Asteraceae representatives. Mature glandular trichomes of Artemisia campestris ssp. maritima located on leaves were $58 \mu \mathrm{m}$ high [16], the height of Artemisia nova hairs was in the range of 82-91 $\mu \mathrm{m}$ [31], and long-stalked Sigesbeckia jorullensis trichomes had a height of 40-80 $\mu \mathrm{m}$ [19]. The diameter of trichomes 
measured at the level of the head ranged from 50 to $117 \mu \mathrm{m}$, depending on the species [12,16,18,19,31].

In the species investigated in the present study, the secretion was accumulated in the subcuticular space, which agrees well with the results reported by other authors who analysed trichomes in a variety of Asteraceae representatives [2,5,8,10-16,20,32-34]. In Chrysanthemum morifolium only, the secretory material was additionally accumulated along the outer edge of the second trichome cell tier $[13,14]$. In Inula helenium examinated trichomes, release of the secretion proceeded through rupture of the cuticle in the apical part of the subcuticular space. A similar secretion mechanism was observed in other Asteraceae representatives [7,9,10,18,20]. Werker and $\mathrm{Fahn}$ [9] describe release of the secretory substance through cuticular pores or through cuticle rupture and pores concurrently. In Inula helenium examinated hairs, expansion of the subcuticular space and accumulation of secretion were accompanied by gradual degradation of trichome cells beginning from the top layers. This is in agreement with observations reported by other authors, who noticed additionally that plastids were the first organelles to undergo lysis and mitochondria were the only organelles persisting until cell collapse [14,27]. R u miń s k a [35] reports that degenerating secretory cells in Achillea millefolium trichomes lost not only the capability of essential oil synthesis and secretion but also the ability to contact with the rest of the live organism.

Besides glandular trichomes, covering hairs were also found in the investigated species. The general characteristics of non-glandular trichomes described by $\mathrm{Matcalfe}$ and $\mathrm{Chalk}$ [23] suggest that Inula helenium trichomes can be classified as hairs with a unicellular or multicellular stalk and an elongated whip-like apical cell. Werker and Fahn [9] described trichomes in a related species Inula viscosa to be very long and formed of 5-6 basal and 2-4 apical cells. In turn, Nikolaki and Christodulakis [34] reported that non-glandular trichomes in I. viscosa are composed of ca. 10 rosette-forming basal cells, 5 stalk cells arranged vertically, and a narrow, strongly elongated apical cell. In Stevia rebaudiana, two types of non-glandular trichomes were distinguished, i.e. long $(300-500 \mu \mathrm{m}) 7-10$ celled hairs and short $(80-150$ $\mu \mathrm{m})$ 5-7-celled trichomes [12].

The mechanical trichomes of Inula helenium exhibited a viable protoplast. Besides their protective role, these trichomes serve a secretory function, which was evidenced by the positive results of the histochemical assays. This may correspond with the finding that in many plant species glandular trichomes are phylogenetically related to non-glandular hairs $[3,4]$.

\section{CONCLUSIONS}

1. All above-ground organs of Inula helenium bear glandular and covering trichomes. Glandular trichomes are most abundant on the abaxial surface of leaves and ray-floret corollas, whereas the highest density of mechanical hairs was found on the both surfaces of involuclar bracts.

2. Glandular trichomes exhibit a biseriate structure. They are classified into two types: sessile and stalk hairs.

3. Mechanical trichomes are uniseriate, multi-celled, and have an elongated apical cell.

4. Glandular trichomes produce lipid substances and polyphenols.

5. Covering trichomes may participate in secretion of secondary metabolites, as chemical compounds have been detected in their apical cells.

\section{Acknowledgments}

Research supported by Poland's Ministry of Science and Higher Education as part of the statutory activities of the Department of Botany, Univeristy of Life Sciences in Lublin.

\section{REFERENCES}

1. Szweykowska A, Szweykowski J. Słownik Botaniczny. Wiedza Powszechna, Warszawa; 2003. (in Polish)

2. Lewkowicz-Mosiej T. Leksykon roślin leczniczych. Świat Książki, Warszawa; 2003. (in Polish)

3. Fahn A. Secretory tissues in vascular plants. New Phytol. 1988; 108: 229-257. http://dx.doi.org/10.1111/j.1469-8137. 1988.tb04159.x

4. Fahn A. Secretory tissues and factors influencing their development. Phyton. 1988; 28(1): 13-26.

5. Fahn A. Structure and function of secretory cells. Adv Bot Res. 2000; 31: 37-75. http://dx.doi.org/10.1016/S0065-22 96(00)31006-0

6. Ki m E-S, Mahlberg P.G. Secretory cavity development in glandular trichomes of Cannabis sativa L. (Cannabaceae)., Amer. J. Bot. 1991; 78(2): 220-229.

7. Duke MV, Paul RN, Elsohly HN, Sturtz G, $\mathrm{Duke} \mathrm{SO}$. Lokalization of artemisinin and artemisitene in foliar tissues of glanded and glandless biotypes of Artemisia аппиа L. Int J Plant Sci. 1994; 155(3): 365-372.

8. Werker E, Putievsky E, Ravid U, Dudai N, Katzir I. Glandular hairs, secretory cavities, and the essential oil in leaves of tarragon (Artemisia dracunculus L.). J Herbs, Spices \& Medicinal Plants. 1994; 2(3): 19-32.

9. Werke r E, F a h n A. Secretory hairs of Inula viscosa (L.) AIT. Development, ultrastructure, and secretion. Bot Gaz. 1981; 142(4): 461-476. http://dx.doi.org/10.1086/337247

10. Afolayan AJ., Meyer JJM. Morphology and ultrastructure of secreting and nonsecreting foliar trichomes 
of Helichrysum aureonitens (Asteraceae). Int J Plant Sci. 1995; 156(4): 481-487. http://dx.doi.org/10.1086/297270

11. Ascensăo L, Silva JAT, Barroso JG, Figueiredo AC, Pedro LG. Glandular trichomes and essential oils of Helichrysum stoechas. Israel J Plant Sci. 2001; 49: 115-122. http://dx.doi.org/10.1092/F85YYEN4-9VTF-B1AJ

12. Bondarev NI, Sukhanova MA, Semenova GA, Goryaeva OV, Andreeva SE, Nosov AM. Morphology and ultrastructure of trichomes of intact and in vitro plants of Stevia rebaudiana Bertoni with reference to biosynthesis and accumulation of steviol glycosides. Moscow Univ Biol Sci Bull. 2010; 65(1): 12-16. http://dx.doi.org/10. 3103/S0096392510010037

13. Vermeer J, Peterson RL. Glandular trichomes on the inflorescence of Chrysanthemum morifolium cv. Dramatic (Compositae). I. Development and morphology. Can J Bot. 1979 a; 57: 705-713.

14. Vermeer J, Peters on RL. Glandular trichomes on the inflorescence of Chrysanthemum morifolium cv. Dramatic (Compositae). II. Ultrastructure and histochemistry. Can J Bot. 1979 b; 57: 714:729

15. A s cen săo L, Pa is MS. Secretory trichomes from $A r$ temisia crithmifolia: some ultrastructural aspects. Bull Soc Bot Fr. 1982: 129(1): 83-87.

16. A s cen să o L., Pa is M. S.S. Glandular trichomes of Artemisia campestris (ssp. maritima): ontogeny and histochemistry of the secretory product. Bot Gaz. 1987; 148(2): 221-227. http://dx.doi.org/10.1086/337650

17. Duke SO, Paul RN. Development and fine structure of the glandular trichomes of Artemisia апnиа L. Int J Plant Sci. 1993; 154(1): 107-118. http://dx.doi.org/10. 1086/297096

18. Cornara L, Bononi M, Tateo F, SerratoValenti G., Mariotti M.G. Trichomes on vegetative and reproductive organs of Stevia rebaudiana (Asteraceae). Structure and secretory products. Plant Biosyst. 2001; 135(1): 25-37.

19. Heinrich G., Pfeifhofer H. W., Stabentheiner E, Sawidis T. Glandular hairs Sigesbeckia jorullensis Kunth (Asteraceae): morphology, histochemistry and composition of essential oil. Ann Bot. 2002; 89: 459-469. http://dx.doi.org/10.1093/aob/mcf062

20. Sulborska A. Micromorphology of flowers, anatomy and ultrastructure of Chamomilla recutita (L.) Rausch. (Asteraceae) nectary. Acta Agrobot. 2011; 64(4):23-34. http:// dx.doi.org/10.5586/aa.2011.043

21. Milan P, Hayashi AH, Appezzato-da-Glória B. Comparative leaf morphology and anatomy of three Asteraceae species. Braz Arch Biol Techn. 2006; 49(1): 135-144. http://dx.doi.org/10.1590/S1516-89132006000100016

22. R a m a y a N. Models of development in the trichomes of Compositae. Curr Sci. 1963; 32(1):27-28.

23. Metcalfe CR, Chalk L. Anatomy of the Dicotyledons. V. II. Oxford at the Clarendon Press; 1957.

24. Carlquist S. Structure and ontogeny of glandular trichomes of Madinae (Compositae). Amer J Bot. 1958; 45: 657-682. http://dx.doi.org/10.2307/2439504
25. Ferreira JFS, Janick J. Floral morphology of Artemisia annua with special reference to trichomes. Int. J Plant Sci. 1995; 156(6): 807-815. http://dx.doi.org/10. 1086/297304

26. Spring O. Chemataxonomy based on matabolities from glandular trichomes. Adv Bot Res. 2000; 31: 153-174.

27. Uph of JCT, Hummel K. Plant hairs. Handbuch der Pflanzenanatomie. Bd. IV, Tl. 5. Gebrüder Borntraeger, Berlin; 1962.

28. Wagner GJ. Secreting glandular trichomes: more than just hairs. Plant Physiol. 1990; 96: 675-679. http://dx.doi. org/10.1104/pp.96.3.675

29. Kołdowski M, Wysocka-Rumińska A, Tałałaj S, Wiszniewski J. Rośliny olejkowe i olejki naturalne. Państwowe Wydawnictwo Rolnicze i Leśne, Warszawa; 1955. (in Polish)

30. Figueiredo AC, Pais MS. Ultrastructural aspects of glandular cells from the secretory trichomes and from the cell suspension cultures of Achillea millefolium L. ssp. millefolium. Ann Bot. 1994; 74: 179-190. http://dx.doi. org/10.1006/anbo.1994.1107

31. Kelsey R.G., Shafizadeh F. Glandular trichomes and sesquiterpene lactones of Artemisia nova (Asteraceae). Bioch Syst Ecol. 1980; 8: 371-377. http://dx.doi.org/10. 1016/0305-1978(80)90039-3

32. Spring O, Bienert U. Capitate glandular hairs from sunflower leaves: development, distribution and sesquiterpene lactone content. J Plant Physiol. 1987; 130: 441-448. http://dx.doi.org/10.1016/S0176-1617(87)80209-2

33. Corsi G. Nencioni S. Secretory sructures in Artemisia nitida Bertol. (Asteraceae). Israel J Plant Sci. 1995; 43: 359-365.

34. Nikolaki A, Christodulakis NS. Leaf structure and cytochemical investigation of secretory tissues in Inula viscosa. Bot J Linnean Society. 2004; 144: 437-448. http:// dx.doi.org/10.1111/j.1095-8339.2003.00264.x

35. Rumińska A. Ilościowe i morfologiczne zmiany gruczołków olejkowych w ciągu rozwoju koszyczków kwiatowych Achillea millefolium L. Acta Agrobot. 1966; XVIII: 5-18. (in Polish)

\section{Struktura i rozmieszczenie włosków gruczołowych i niegruczołowych na nadziemnych organach Inula helenium $\mathbf{L}$. (Asteraceae)}

\section{Streszczenie}

Przy zastosowaniu mikroskopii świetlnej oraz skaningowej elektronowej (SEM) badano mikromorfologię oraz rozmieszczenie włosków gruczołowych i niegruczołowych na nadziemnych częściach roślin Inula helenium $\mathrm{L}$.

Zarejestrowano dwa typy dwurzędowych włosków gruczołowych: siedzące i trzonkowe oraz włoski okrywające. Siedzące włoski gruczołowe stwierdzono 
na wszystkich badanych organach I. helenium z największym zagęszczeniem na abaksjalnej powierzchni liści, kwiatów rurkowatych oraz łodygach, zaś włoski trzonkowe zlokalizowane były na liściach i łodygach. Włoski siedzące cechowały się nieco mniejszą wysokością $(58-103 \mu \mathrm{m})$ i zbliżoną szerokością $(32-35 \mu \mathrm{m})$ w porównaniu z włoskami trzonkowymi $(62-111 \mu \mathrm{m}$ x 31-36 $\mu \mathrm{m})$. Włoski gruczołowe zbudowane były z 5-7 (włoski siedzące) lub 6-9 pięter komórek (włoski trzonkowe). Komórki apikalnych pięter włosków wykazywały cechy komórek wydzielniczych. Wydzielina gromadziła się $\mathrm{w}$ przestrzeni subkutykulanej, po czym kutykula pękała na szczycie uwalniając zawartość. Testy histochemiczne wykazały, że we włoskach gruczo- łowych występowały lipidy oraz polifenole. Nie stwierdzono natomiast skrobi.

Włoski niegruczołowe obserwowano najczęściej na listkach okrywy koszyczka, rzadziej na liściach i łodygach. Strukturę tych włosków tworzyło od 2 do 9 komórek, przy czym komórki bazalne (1-6) były mniejsze, ułożone szeregowo, zaś komórki szczytowe cechowały się prozenchymatycznym kształtem. Komórka apikalna była najdłuższa i ostro zakończona. Przeprowadzone testy histochemiczne ujawniły pomarańczowo-czerwoną barwę (obecność lipidów) i brązową (obecność polifenoli) w szczytowych komórkach włosków. Może to sugerować, że włoski te oprócz roli ochronnej biorą również udział w wydzielaniu metabolitów wtórnych.

Handling Editor: Elżbieta Weryszko-Chmielewska

This is an Open Access digital version of the article distributed under the terms of the Creative Commons Attribution 3.0 License (creativecommons.org/licenses/by/3.0/), which permits redistribution, commercial and non-commercial, provided that the article is properly cited.

(CThe Author(s) 2013 Published by Polish Botanical Society 